\title{
Distributional range expansion of the parasitic wasp Lirata batesella (Westwood, 1874) (Hymenoptera, Eucharitidae)
}

\author{
Nelson W. Perioto ${ }^{ \pm}$, Rogéria I. R. Lara \\ Instituto Biológico, Ribeirão Preto, São Paulo, Brazil. \\ 表=“Corresponding author: nperioto2@gmail.com
}

Edited by: Daniel Aquino

Received: October 05, 2021. Accepted: December 06, 2021. Published: December 23, 2021.

Abstract. This study is focused on the expansion of the distributional range of Lirata batesella (Westwood, 1874) (Hymenoptera, Eucharitidae) and based on a single female specimen deposited at Coleção Entomológica do Laboratório de Sistemática e Bioecologia de Predadores e Parasitoides of the Instituto Biológico, in Ribeirão Preto, São Paulo state, Brazil. Santarém, in Pará state, Brazil, the type locality, is the only known distribution record for the species. Here, we provide a new distribution record for L. batesella, in Luiz Antônio, São Paulo state, about 2,200 km south of the type locality, which represents a significant increase in its distribution range. A map showing the geographical distribution of $L$. batesella based on the new record and literature is provided.

Keywords: ant parasitoids, Brazilian woodland savanna, Chalcidoidea, Estação Ecológica de Jataí, Eucharitinae.

Eucharitidae is a unique family among the Chalcidoidea (Hymenoptera): all their species whose biologies are known act as koinobiont, larval-pupal ectoparasitoids of ants (Clausen 1940; 1941; Heraty 1985; 1994; 2000; 2002; Murray \& Heraty 2019; Lachaud \& Pérez-Lachaud 2012), which makes these insects the largest and most diverse group of Hymenoptera parasitoid of eusocial insects (Heraty 2002; Schoeninger et al. 2021). Currently, about sixty genera and approximately 500 extant species of Eucharitidae are described, with occurrence records for almost all zoogeographic regions of the world and greater diversity and abundance in tropical regions (Heraty 2002; Torréns 2013; Silva et al. 2019; Schoeninger et al. 2021).

Erected in 1884 by Cameron, Lirata (Hymenoptera, Eucharitidae) are a small and monophyletic group of Neotropical chalcid parasitic wasps that currently includes nine species, eight of them with reported occurrence for Brazil: L. basistriata Schoeninger et al., 2021 for the state of Amapá, L. batesella (Westwood, 1874) for the state of Pará, L. diabla Heraty, 2002 for the state of Minas Gerais, L. luteogaster Cameron, 1884 for the state of Amazonas, L. maranhensis Schoeninger et al., 2021 for the state of Maranhão, L. pallescens (Walker, 1862) for the state of Amazonas, L. pustula Heraty, 2002 for the states of Bahia, Goiás and São Paulo, and L. striatissima (Walker, 1862) for the states of Amazonas and Pará (Heraty 2002; Schoeninger et al. 2021).

Lirata batesella (Fig. 1) was described by Westwood (1874) based on specimens collected from Brazil (type locality: Santarém, state of Pará), and so far, nothing is known about its natural history (Schoeninger et al. 2021).

Our knowledge about the fauna of Brazilian Lirata and its distribution is poor and incomplete. There are no records of $L$. batesella in areas of Brazilian savanna. Thus, we present the first record of $L$. batesella in an area of Brazilian woodland savanna in the state of São Paulo, southeastern Brazil.

A single specimen of $L$. batesella was collected with Malaise trap at Estação Ecológica de Jataí, located in the municipality of Luiz Antônio, São Paulo state, Brazil despite the large collection effort employed (4380 trap-days with Malaise traps, 1690 trap-days with Moericke traps and 624 trap-days with light traps). The collect protocol used at EEJ is detailed in Versuti et al. (2014).

The studied specimen was deposited at Coleção Entomológica do Laboratório de Sistemática e Bioecologia de Predadores e Parasitoides of the Instituto Biológico (LRRP), in Ribeirão Preto, São Paulo state, Brazil (N.W. Perioto, curator).

The species was identified primarily by John M. Heraty (University of California, Riverside) from a picture published by the first author on the "Hymenopterist Forum", on Facebook@ on July 9, 2021. The generic and specific identifications were later confirmed through the identification keys provided by Silva et al. (2019) and Schoeninger et al. (2021), respectively. The consistency of anatomical data with the Hymenoptera Anatomy Ontology project (Yoder et al. 2010; Seltmann et al. 2012) was determined using the proofing tool available in the Hymenoptera Glossary (HAO 2019), except for the frenal processes that refers to the paired spines of the mesoscutellum that arise from the frenum (character 50; Heraty 2002). The details on body sculpture follows Harris (1979).

The images were taken using a Leica MC170 HD digital camera coupled to a Leica M205C APO stereomicroscope and the specimen was illuminated with a Leica LED5000 HDI high diffuse dome illumination. The images were combined by using the Helicon Focus (version 5.3) software and the figures prepared using the Adobe Photoshop (version 11.0) software.

The provided map with the geographical distribution of L. batesella was generated with the Google MyMaps tool available at https://www. google.com.br/maps and is based on data from literature and new records.

The information on the labels of the examined specimens has been transcribed in the examined material section as follows: the backslash symbol ( $\backslash$ ) indicates the different lines on the label and two quotation marks ( " ") indicate different labels on the same specimen.

\section{Lirata batesella (Westwood, 1874)}

\section{Figs. 1-2}

New record. Luiz Antônio, São Paulo state, Brazil (Fig. 2).

Examined material. "Brasil / SP / Luiz Antônio \Brazilian woodland

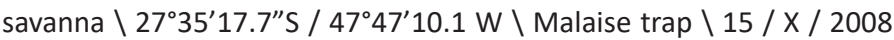
$\backslash$ N.W. Perioto e eq., cols."; "Lirata \batesella \(Westwood, 1874) \ Perioto, N.W., det. 2021"; 1 female (LRRP \# 22535).

Identification. According Heraty (2002) and Schoeninger et al. (2021) L. batesella can be recognized for having the first flagellomere longitudinally ribbed; face, mesoscutellar disc and metacoxa very 
fine rugulose and bare; mesoscutum transversely carinate and frenal processes cylindrical, scabriculous.

Discussion. The only data regarding the distribution of L. batesella available in the literature is Santarém, Pará state, Brazil, the type locality (Westwood 1874). Despite the scarcity of data in the distribution of this species John Heraty (personal communication) claimed to have seen several specimens in various collections outside Brazil. This new record extends the geographical distribution of $L$. batesella to Luiz Antônio, São Paulo state, about 2,200 km south of the type locality representing a significant increase in the distribution range in Brazil and indicates that this species can develop in the Cerrado biome.
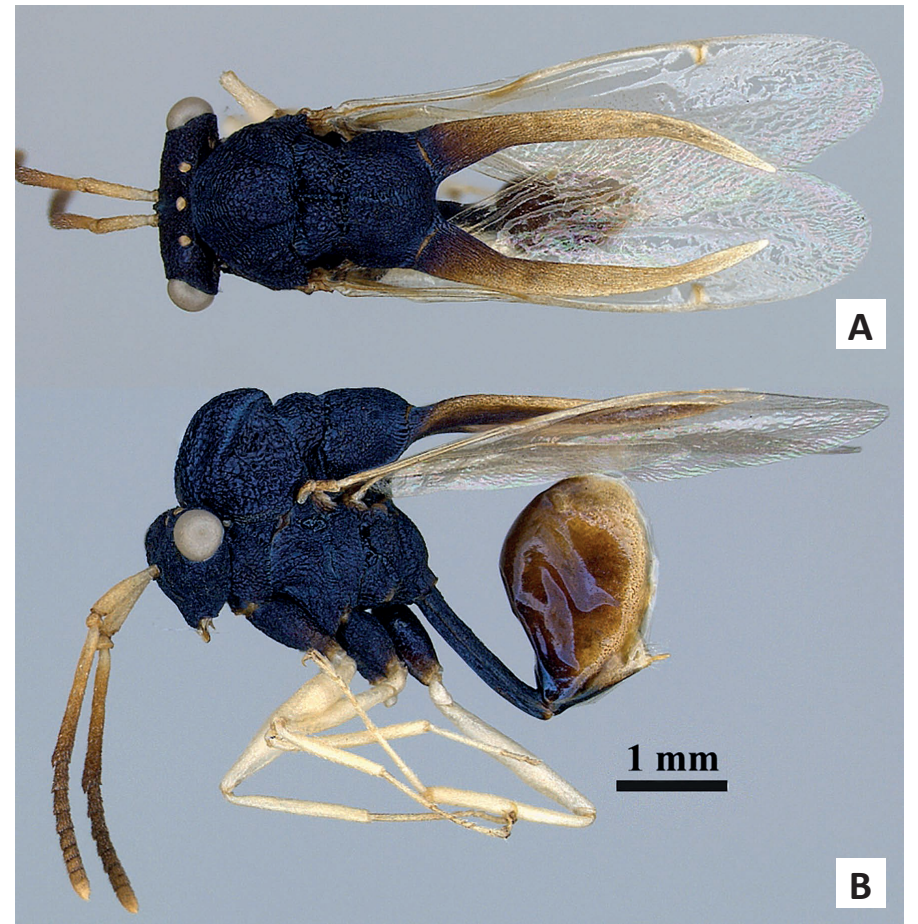

Figure 1. Lirata batesella (Westwood, 1874) (Hymenoptera, Eucharitidae). A. dorsal view; B. habitus.

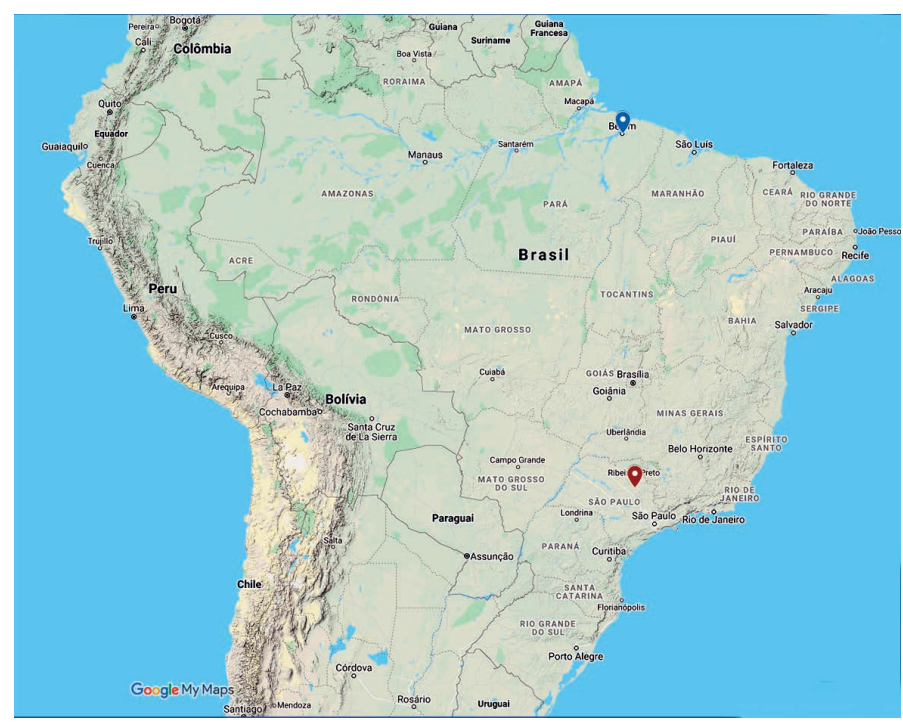

Figure 2. Geographic distribution of Lirata batesella (Westwood, 1874) (Hymenoptera, Eucharitidae) (blue dot= known record, red dot= new record).

\section{Acknowledgements}

This study was partially founded by the Instituto Nacional de Ciência e Tecnologia dos Hymenoptera Parasitoides (CNPq/Fapesp/ Capes). We also thank John M. Heraty for additional feedback, and Karine Schoeninger and the anonymous reviewers for their critical reading.

\section{Authors' Contributions}

N.W.P. and R.I.R.L. planned the sample design, performed the collections and contributed with the writing, preparation of distribution maps, edition and revision of the final manuscript. N.W.P. identified the Eucharitidae.

\section{References}

Clausen, C. P. (1940) The immature stages of the Eucharidae. Proceedings of the Entomological Society of Washington, 42(8): 161-170.

Clausen, C. P. (1941) The habits of the Eucharidae. Psyche, 48: 57-69. doi: $10.1155 / 1941 / 21539$

HAO (2019) Hymenoptera Anatomy Consortium. Accessed on 29 Jun 2021. Available at http://glossary.hymao.org.

Harris, R. A. (1979) A glossary of surface sculpturing. Occasional Papers in Entomology, 28; 1-31.

Heraty, J. M. (1985) A revision of the Nearctic Eucharitinae (Hymenoptera: Chalcidoidea: Eucharitidae). Proceedings of the Entomological Society of Ontario, 85: 61-103. doi: 10.5962/bhl. title.53489

Heraty, J. M. (1994) Classification and evolution of the Oraseminae in the Old World, with revisions of two closely related genera of Eucharitinae (Hymenoptera: Eucharitidae). Life Sciences Contributions No. 157. Toronto, Royal Ontario Museum.

Heraty, J. M. (2000) Phylogenetic relationships of Oraseminae. Annals of the Entomological Society of America, 93: 374-390. doi: 10.1603/0013-8746(2000)093[0374:PROOHE]2.0.CO;2

Heraty, J. M. (2002) A revision of the genera of Eucharitidae (Hymenoptera: Chalcidoidea) of the world. Memoirs of the American Entomological Institute, 68: 1-377.

Lachaud, J.-P.; Pérez-Lachaud, G. (2012) Diversity of species and behavior of hymenopteran parasitoids of ants: a review. Psyche, Article ID 134746: 1-24. doi: 10.1155/2012/134746

Murray, E. A.; Heraty, J. M. (2019) Neotropical ant parasitoids (Hymenoptera: Eucharitidae): interpreting taxonomy, phylogeny and divergent morphologies. Systematic Entomology, 45(2): 464480. doi: 10.1111/syen.12407

Seltmann, K. C.; Yoder, M. J.; Mikó, I.; Forshage, M.; Bertone, M. A.; Agosti, D.; Austin, A. D.; Balhoff, J. P.; Borowiec; M. L.; Brady, S. G., et al. (2012) Hymenopterists' guide to the Hymenoptera Anatomy Ontology: utility, clarification, and future directions. Journal of Hymenoptera Research, 27: 67-88. doi: 10.3897/JHR.27.2961

Silva, T. S. R.; Silva-Freitas, J. M.; Schoeninger, K. (2019) A synopsis of the Brazilian Eucharitidae (Hymenoptera: Chalcidoidea) fauna: an annotated checklist of the family in the country, with a revised key for the New World genera. Zootaxa, 4564(2): 347-366. doi: 10.11646/zootaxa.4564.2.3

Schoeninger, K.; Torréns, J.; Dominguez, C.; Silva-Freitas, J. M. (2021) New species of Lirata Cameron (Hymenoptera: Eucharitidae) with an identification key and phylogenetic analysis. Zoologischer Anzeiger, 293: 263e272. doi: 10.1016/j.jcz.2021.06.013

Torréns, J. (2013) A review of the biology of Eucharitidae (Hymenoptera: Chalcidoidea) from Argentina. Psyche, Article ID 926572: 1-14. doi: 10.1155/2013/926572

Versuti, D. R.; Paz, C. C. P.; Lara, R. I. R.; Fernandes, D. R. R.; Perioto, N. W. (2014) Comparative abundance and diversity of Dryininae (Hymenoptera, Dryinidae) in three savannah phytophysiognomies in southeastern Brazil, under three sampling methods. Revista Brasileira de Entomologia, 58(3): 273-279. doi: 10.1590/S008556262014000300008

Westwood, J. O. (1874) Thesaurus Entomologicus Oxoniensis; or illustrations of new, rare, and interesting insects, for the most part contained in the collections presented. London, University of Oxford.

Yoder M. J.; Mikó, I.; Seltmann, K. C.; Bertone, M. A.; Deans, A. R. (2010) A gross anatomy ontology for Hymenoptera. PLOS ONE, 5(12): e15991. doi: 10.1371/journal.pone.0015991 